\title{
PPP2CA wt Allele
}

National Cancer Institute

\section{Source}

National Cancer Institute. PPP2CA wt Allele. NCI Thesaurus. Code C49433.

Human PPP2CA wild-type allele is located in the vicinity of $5 q 31.1$ and is approximately 30 $\mathrm{kb}$ in length. This allele, which encodes serine/threonine-protein phosphatase 2A catalytic subunit alpha isoform protein, plays a role in the dephosphorylation of phosphoproteins. 